\title{
PERFORMANCE OF WIND TURBINE VENTILATOR AS ELECTRICITY GENERATOR IN BOAT FISHING
}

\author{
Corvis L Rantererung ${ }^{1}$, Kristiana Pasau ${ }^{2}$ \\ ${ }^{I}$ Department of Mechanical Engineering, Paulus Christian University of Indonesia, Makassar, Indonesia \\ ${ }^{2}$ Department of Mechanical Engineering, Paulus Christian University of Indonesia, Makassar, Indonesia \\ corvisrante@yahoo.com
}

\begin{abstract}
The specific objective of the research activities is to produce a package of wind power technology in the fishing boat without fuel, strengthen energy independence for fishermen, achievement data performance wind power plant in a fishing boat. The method used is to testing wind turbine ventilator as power plants in the fishing boat. Wind turbine ventilator, wind energy capture from multiple directions. This wind turbine receives wind energy then converts the kinetic energy of wind into mechanical energy for rotating electrical generator. This electrical energy is stored in batteries to stabilize the flow of electricity from the battery and then used as a source of energy for lighting fishing boat.
\end{abstract}

Key Words: Wind Turbine Ventilator, Power, Electricity

\section{INTRODUCTION}

Almost all countries in the world have the problem of energy, including Indonesia also experienced a severe energy crisis problem, both in price and availability. The economic crisis that has occurred since the end of the new order, greatly affect the power generation capacity addition [1]. . The oceans that are in the equatorial region has a wealth of fish and abundant wind energy potential but have not been optimal utilization and management, fishermen we are still relatively poor and marginalized. Fishermen are very burdened by the cost of fuel the engine of the boat and lights at night to catch fish.

Fishermen at the time of sailing throughout the night even weeks or months in desperate need of electrical energy for lighting (lighting) sailboat fishing, cooking, pumping water out of the boat, Freeser to keep fish, food and medicines remained good. Also electricity is used for information and communication means such as radio, television and mobile phones. At the present time only a sailboat equipped with lights strongkin as a torch so that the fish in the sea at night can approach the boat, then the fish fished and caught by fishermen.

Another problem experienced by the fishermen when the high waves and heavy rains accompanied by strong winds, the boats and the water intruding lighting on and off even broken so that the fishermen keolahan and prustrasi when fishing. Then to a fishing boat that just use the screen as a driver also having problems because the boat can only drove in the direction of wind and very difficult to be directed / deflected towards the other, so it is necessary propulsion boat without fuel such as ventilator wind turbine power generation [2]. . The utilization of wind energy as an alternative source of energy very well as a producer of mechanical or electrical energy. Wind energy is energy that is environmentally friendly because it does not produce carbon dioxide emissions. Wind energy as a clean energy source that has an enormous potential,

but in its use is still very small [3]. Fishermen are very burdened by the cost of fuel the engine of the boat and lights at night to catch fish. Fishermen at the time of sailing throughout the night even weeks or months in desperate need of electrical energy for lighting (lighting) sailboat fishing, cooking, pumping water out of the boat, Freeser to keep fish, food and medicines remained good. At the present time only a fishing boat equipped with lights strongkin as a torch so that the fish in the sea at night can approach the boat, then the fish fished and caught by fishermen . On a fishing boat having an enormous potential for wind power because wind energy at the boat fishing is a combination of natural wind currents and wind currents due to the rate of movement of the boat, it can be used as an energy source driving the boat and power plants in a fishing boat. In addition, wind energy conversion system is able to replace the function of stronkin lights or driving in a fishing boat enginesThe boat is a means of sea transport that utilize wind power through a screen installed at the boat so that the boat sped ahead. The fishing boat is also used fishermen to catch fish at night.

Turbine ventilator so far only used in the ventilation system to circulate air in the room, which is widely mainly in industry, warehousing, workshops, and even household as air conditioning. Development of turbine ventilator use for power generation is the addition of modifier component of the mechanical energy into electrical energy [4]. The wind turbines as power generation is having several vertical blades have better aerodynamic performance than with sumbuh horizontal wind turbine that has a better performance wind turbine with a simple construction that is suitable for use in a fishing boat. Wind turbine concept is quite simple and practically not affected by wind direction. 
Wind is one form of energy available in nature, wind power plants convert wind energy into electrical energy using wind turbines or wind turbine

Testing in the bathroom, the results achieved that the rate of air flow into the room further increased and is able to perform mixing outside air so that the indoor air to be fresh. Turbine performance ventilator is able to deliver positive results in the discharge of air ventilation shaft rotation in $1500 \mathrm{rpm}$ with a wind speed of $5 \mathrm{~m} / \mathrm{s}$. Based on literature bebarapa, wind speed in Indonesia blowing at a speed of $3 \mathrm{~m}$ / $\mathrm{s}$ to $20 \mathrm{~m} / \mathrm{s}$.

The wind was blowing around the building or over a rough surface, causing changes in wind speed and direction, and it's called turbelensi. Turbelensi will reduce the power output of the mill and the mill will cause vibrate. At the top of the hill, the largest wind speed, this is caused by the friction of the wind. Hill serves as a concentrator of the flow of air, causing the air accelerated on a hilltop. Generally, the above effect is stronger when the hill is rather smooth and not too steep nor too flat. The ideal slope $16^{\circ}$, in practice can be taken slope $6^{0}$ up to $16^{\circ}$. the angle of $27^{0}$ should be avoided.

According to Anonymous, 2009, that the wind turbines as power generation is having several vertical blades have better aerodynamic performance than with sumbuh horizontal wind turbine that has a better performance wind turbine with a simple construction that is suitable for use in a fishing boat. Wind turbine concept is quite simple and practically not affected by wind direction. Wind is one form of energy available in nature, wind power plants convert wind energy into electrical energy using wind turbines or wind turbines.

Based on the above, the research activities of this program will design a wind turbine ventilator as power generation and propulsion on a fishing boat. Wind energy as a source of renewable energy, the amount of wind energy is abundant in ocean Indonesia and has potential as a solution to the reduction of dependence on fossil energy sources, but unfortunately still not used optimally for the welfare of fishermen and Indonesian society in general

The working principle is quite simple ventilator wind turbine, wind energy wind turbines rotate, forwarded to rotate the rotor in the generator at the rear of the wind turbines, which will produce electrical energy. This electrical energy will usually be stored in the battery before it can be utilized [5].Mass of air or wind flow velocity (V), through a broad cross section of the blade with (A) states the mass flow rate of air or wind ( $\dot{m}$ ) with the following relation :

$\dot{m}=\rho \cdot A \cdot V(\mathrm{~kg} / \mathrm{s})$

then the kinetic energy of the wind stream flow per second or wind power by the following equation :

$P_{k i n}=1 / 2 m V^{2}$

(Watt)

Wind turbine power (power input) can be expressed by the following equation:

$\mathrm{P}_{\mathrm{t}}=\rho \mathrm{AV}^{3} \quad$ (Watt)

\author{
Description: \\ Pt: Input power (Watts), \\ $\rho$ : Density of air $(\mathrm{kg} / \mathrm{m} 3)$ \\ A: Wind Turbi cross-sectional area $(\mathrm{m} 2)$ \\ $\mathrm{V}$ : Wind speed $(\mathrm{m} / \mathrm{sec})$.Keterangan:
}

Some effect on the placement of a wind mill that need to be considered include :( a).Friction where the wind low wind speeds close to (b) Turbulensi on area usually located behind buildings, hills and other . (c) .Acceleration, occurred at the height of hills, mountains and others.

To calculate how the power generated by the wind turbine generator to the ventilator [6], can be calculated using the following equation :

$\mathrm{P}_{\mathrm{o}}=\mathrm{V} \mathrm{I}$ (Watt)

\section{Description:}

$\mathrm{P}_{\mathrm{o}}$ : output power (Watt)

$\mathrm{V}$ : voltage (Volt)

I: Current (Amperes)

Efficiency of the resulting wind turbine ,can be calculated by the following equation:

$$
\eta=\frac{P_{0}}{P_{t}} \times 100 \%
$$

\section{Description: \\ $\eta$ : Turbine Efficiency (\%) \\ $\mathrm{P}_{\mathrm{o}}$ : output power (Watt) \\ $\mathrm{P}_{\mathrm{t}}$ : Input power (Watt)}

Relationship above stated three important things [7].are:

- The wind power is proportional to the density of air. This means that in mountainous areas, wind power is lower than that of wind power in the lowlands for the same wind speed

- The wind power is proportional to the broad field of the rotor or proportional to the square of the diameter of the rotor

- wind power is proportional to the cube of the wind speed, so the placement of turbines should be in a location that has a high wind speed, wind speed increase will provide additional wind power.

- The power output of the wind turbine rotor increases with the cube of speed. This means that the placement of turbines should be in place that has the highest wind speeds in the area. The choice of location is rather easy in low-lying but hilly and mountainous areas of the elections is rather difficult.Wind Turbine ventilator with the axis or shaft made and mounted on a fishing boat. Vertical Turbine will rotate the blade in the horizontal direction. It focuses on the impulse turbine wind_energi converted into rotation in the wind turbine ventilator. The main components of a wind turbine is a vertical axis[8] by the following: 


\section{a). Rotor}

The wind turbine rotor blade ventilator has some (blade) whose role is to capture the wind, changing to kinetic energy and then into energy wind turbine rotor rotation. The wind then turn the rotor will convert wind energy to continue the rotation to a generator to produce electricity. The performance shown by the rotor rotational speed of the rotor and the torque generated for each wind speed.

\section{b). Alternator}

Alternator is one very important component. This car alternator harness wind power rotation is then converted into DC electrical power which is supplied to the accumulator. Therefore, it is not required of operators to operate the working of the alternator. Alternator to generate electrical power which is desired on the alternator shaft speed below $1000 \mathrm{rpm}$. Specifications desired voltage is slightly above 12 volts to ensure the process of charging the battery. Puataran shaft alternator converts the energy into electrical energy and charging the battery.

\section{c). Energy Storage Unit}

As well as other renewable energy sources, energy from wind is also intermittent, not the whole day there although the possibility pembangkitannya can be done day and night. As for the electrical energy needs for lighting produced is steady throughout the night. Given the intermittent supply and demand steady, the energy storage unit is used in the form of one or arrangement 12 volt dry battery. Used wind turbine can have 42 pieces of blade (blade) turbines. Another common type is the type of two turbine blades. So, how do wind turbines make electricity? The wind turbine works as the opposite of a fan, wind turbines use wind to make electricity. Use energy storage device that serves as a back-up for electrical energy. When load power consumption is increased or when the speed

\section{MATERIALS AND METHODS}

This study was conducted in Energy Conversion Laboratory Department of Mechanical Engineering, Universitas Kristen Indonesia Paulus Makassar and in boat Fisherman.

\subsection{Material:}

Alluminium, Pully, Bearings, Shaft, Alternator, Batteries, Cables, Lighting DC, Iron elbow, bolts and nuts

\subsection{Tools:}

One unit of Wind Turbine Ventilator with spefikasi made of Alluminium height $80 \mathrm{~cm}$, width $100 \mathrm{~cm}$, the number of blades 40 pieces, blade thickness $2 \mathrm{~mm}$,Hacksaw, hand gurinda machines, electric welding machine, drilling machine, Wrench Ruler elbow, Stingy stingy round and triangular, digital Anemometer, Tachmter Digital Multimeter analog.

\subsection{Procedures}

Procedures for implementing the activities carried out in several stages, which is described as follows:

1) Re-examine all components of the equipment if installed properly

2) Measuring wind speed, wind turbine shaft rotation by placing the tachometer vertically to the shaft wind turbine ventilator

3) Measure the voltage, current generated powerful alternator, which measure current and voltage by placing a multimeter on both ends of the cable Alternator

4) Install bulbs

5) Turn on the lights

6) The electrical energy from the generator is used as a light fishing boat.

7) Evaluate the performance of wind turbines for generating electricity ventilator in a fishing boat

\section{RESULT AND DISCUSSION}

To determine the physical kondsis Wind Turbine Ventilator system as a generator of electricity generated in research activities and an overview perfomansi this system, here shown in the figure 1 and 2 below :

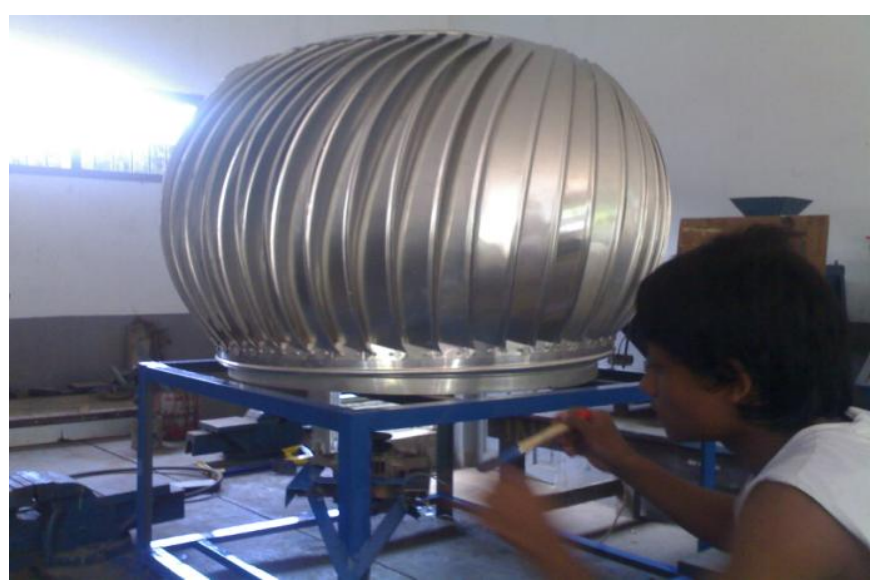

Figure. 1. Wind Turbine Ventilator

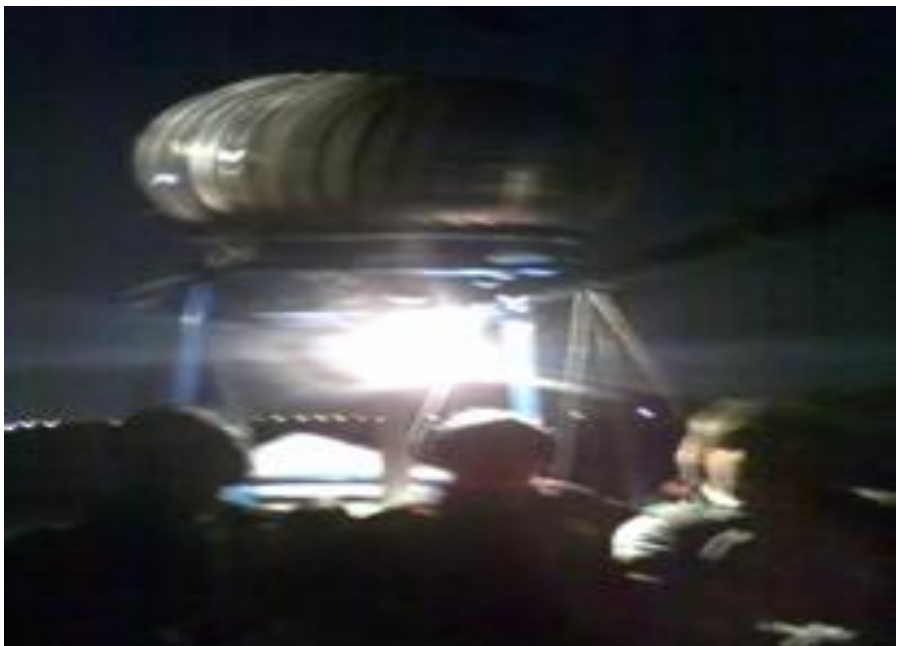

Figure 2. Wind Turbine Ventilator Generating Electricity 
Table1. ResultsofTesting Research

\begin{tabular}{|l|l|l|l|l|l|l|}
\hline $\begin{array}{l}\text { Wind Velocity } \\
(\mathrm{m} / \mathrm{s})\end{array}$ & $\rho$ & $\mathrm{V}$ & $\mathrm{I}$ & $\mathrm{Pt}$ & $\mathrm{Pe}$ & $\eta$ \\
\hline 5 & $\left(\mathrm{~kg} / \mathrm{m}^{-3}\right)$ & $($ Volt $)$ & $($ Ampere $)$ & $($ Watt $)$ & $($ Watt $)$ & $(\%)$ \\
\hline 10 & 1,14439 & 36 & 1,8 & 305,93 & 64.85 & 21,18 \\
\hline 16 & 1,14439 & 53 & 2,2 & 487,47 & 116,6 & 23,91 \\
\hline 18 & 1,14439 & 89 & 4,0 & $1.177,48$ & 373,8 & 31,74 \\
\hline
\end{tabular}

Through this research program, applying Wind Turbine Ventilator type vertical axis for electricity generation in a fishing boat. Suit field conditions that some of the utilization of wind energy, is very good because the wind is a renewable energy source. Utilization was in line at the boat and the fishermen, because the system of small-scale wind energy conversion can use simple technology and relatively low manufacturing cost.

Based on Table 1 gives an explanation that the use of a ventilator turbines generating electricity in a fishing boat, the wind speed of $5 \mathrm{~m} / \mathrm{s}$ capable of generating electric power 305.93 Watt then increased with increasing wind speed and the maximum wind speed of $18 \mathrm{~m} / \mathrm{s}$, capable generate electricity 1676.5 Watt $(1.6 \mathrm{kWatt})$. The application of wind turbine models Ventilator type or vertical axis by simplification-simplification of the model and simple construction, its use is very beneficial.

In Table 1 shows that the greater the wind speed, the power produced by the alternator that is driven by the greater wind turbine ventilator. This happens because the higher the wind speed mean wind power wind turbines are acceptable to move or be converted into electrical energy in the greater Alternator

In Table 1 illustrates that the greater the wind speed the greater the efficiency of the wind turbine as obtained because the power generated greater Alternator. The higher the wind speed, the wind turbines are acceptable power to drive the alternator increases. This tool is used to charge the battery in the boat while at sea. Accu functioning floodlights lit at night in a fishing boat .

According to results on the ground show that the advantages gained in its application the type of turbine is able to operate on all direction of the wind, has great torque, form of construction is quite simple, maintenance is easier and simpler, having initial velocity winds that lower economic value more high.

Load lighting used in boat Fisherman memntuhkan power is too great because on average they use the lights are 200 watts.

The advantages gained in its application types_Angin turbine ventilator is a) It can be operated in all the direction _Angin, b) .It has a large torque, c) .Bentuk fairly simple construction, d) .Pemeliharaan easier and simpler, e). has the initial velocity _Angin lower, f) .It has a higher economic value.
On a fishing boat on average use of 500 and 1000 Watt generator lights in nelyan boat when fishing. In principle that alternative power plants are environmentally friendly, low maintenance costs, $t$ without the need for fuel, because the energy from natural sources for free of charge. It can be said that this plant has a high reliability because it can work for a long time, low operating costs and is environmentally friendly.

\section{CONCLUSION}

[1].Performance Wind Turbine Ventilator is able to convert the kinetic energy of the wind on a fishing boat at a wind speed of $5 \mathrm{~m} / \mathrm{s}$ generating turbine power 305.93 Watt while the maximum wind speed of $18 \mathrm{~m} / \mathrm{s}$ power 1600 Watt.

[2].Wind Turbine Ventilator as the driving Alternator very good because it can generate electrical energy in a fishing boat on a wind speed of $5 \mathrm{~m} / \mathrm{s}$ generate an electric voltage is 36 Volts, the electric current of 1.8 Amperes, 64.85 Watt electric power with a minimum efficiency of $21.18 \%$, then at a wind speed of $18 \mathrm{~m} / \mathrm{s}$ produces a voltage of 105.5 Volts, the electric current of 6.4 Ampere, 672 Watt electric power with a maximum efficiency of the system of this plant is $40.08 \%$.

\section{ACKNOWLEDGEMENTS}

The author would like to deeply express their thanks to the Directorate General of Higher Education, Ministry of Research, Technology and Higher Education Indonesia for its support .

\section{REFERENCES}

[1].Lai,C.M.,2005, Prototype Development of The Rooft of Turbine Ventilators Powered by Hybrid Wind and Photovoltaic Energy .Energy Buildings 38 (2005) 174180

[2].Ming Chun Hsieh, David King Jair, Huann Ming Chou. 2013. The Development of a New Type Rooftop Ventilator Turbine. Engineering, Scientitfic Research 2013, Vol 5.pp.16-20 .

[3].Mody V.J.dan Fernando M.S.U.K. 2009. On the Performance of the Savonius Wind Turbine .Journal of Solar Energy Engineering, Vol.111/71, February 2009.

[4].Mazran Ismail1 \& Abdul Malek Abdul Rahman1.2012. Rooftop Turbine Ventilator, A Review and Update.Journal of Sustainable Development

[5].Beurskens, H.J.M., Wind Energy forWater Pumping in 
Cape Verde, SWD, The Netherlands, 1981

[6].El-Wakil, M.M., 1985, Powerplant Technology, McGraw-Hill Book Co., New York, pp. 589-626 Fox,R.W \& Mc Donald,A.T.1998, Introduction To Fluid Mechanics, $5^{\text {th }}$ Edition, Jhon Wiley and Son,Inc

[7].Hangeveld, H.J., et.al., 1978, Matching of Wind Rotors to Low Power Electrical Generators for a Given Wind Regime, Steering Committee for Wind Energy in Developing Countries, Amsfort, The Netherlands

[8].Khan,N.Su.Y \& Rifat, S.B., 2008. A Review on Wind Driven Ventilation Tehniques, Energy and Building 40 (2008). 1586-1604.

\section{BIOGRAPHIES}

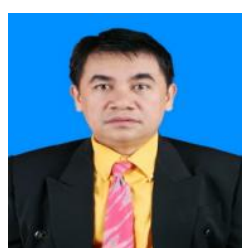

Dr. (candidate). Corvis L Rantererung, Born in Kaero.Kec.Sangalla' 17 Januari 1969. Is a lecturer in the Department of Mechanical Engineering Paulus Christian University of Indonesia, Makassar, Indonesia. Currently now taking Doctoral Program at Brawijaya University in Malang, Indones

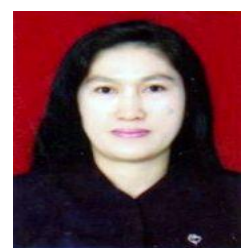

Kristiana Pasau, Born in Tana Toraja 28 Mei 1972. Is a lecturer in the Department of Mechanical Engineering Paulus Christian University of Indonesia, Makassar, Indonesia. 